\title{
EngagedScholarship@CSU
}

Philosophy \& Comparative Religion Department Faculty Publications

Philosophy \& Comparative Religion Department

2015

\section{Abortion, Property, and Liberty}

William Simkulet

Cleveland State University, w.simkulet@csuohio.edu

Follow this and additional works at: https://engagedscholarship.csuohio.edu/clphil_facpub

Part of the Philosophy Commons

How does access to this work benefit you? Let us know!

\section{Publisher's Statement}

The final publication is available at http://link.springer.com/article/10.1007/s10892-015-9201-x/ fulltext.html

\section{Repository Citation}

Simkulet, William, "Abortion, Property, and Liberty" (2015). Philosophy \& Comparative Religion Department Faculty Publications. 22.

https://engagedscholarship.csuohio.edu/clphil_facpub/22

This Article is brought to you for free and open access by the Philosophy \& Comparative Religion Department at EngagedScholarship@CSU. It has been accepted for inclusion in Philosophy \& Comparative Religion Department Faculty Publications by an authorized administrator of EngagedScholarship@CSU. For more information, please contact library.es@csuohio.edu. 


\title{
Abortion, Property, and Liberty
}

\author{
William Simkulet
}

\begin{abstract}
In "Abortion and Ownership" John Martin Fischer argues that in Judith Jarvis Thomson's violinist case you have a moral obligation not to unplug yourself from the violinist. Fischer comes to this conclusion by comparing the case with Joel Feinberg' s cabin case, in which he contends a stranger is justified in using your cabin to stay alive. I argue that the relevant difference between these cases is that while the stranger's right to life trumps your right to property in the cabin case, the violinist's right to life does not trump your right to liberty in the violinist case.
\end{abstract}

Keywords Abortion $\cdot$ Cabin case $\cdot$ Moral responsibility $\cdot$ Moral luck $\cdot$ Rape $\cdot$ Restitution $\cdot$ Rights $\cdot$ Violinist case

\section{Introduction}

Many anti-abortion arguments begin with the assumption that if a fetus is the sort of the thing whose life it is seriously wrong to end-such as a person-then abortion (the killing of a fetus) is also seriously morally wrong. (Noonan 1970; Tooley 1972; Warren 1973; Engelhardt 1974; Devine 1978; Sumner 1981; Feinberg 1986; Marquis 1989; Fischer 2013) In her highly influential paper "A Defense of Abortion," Judith Jarvis Thomson sets out to demonstrate the falsity of this assumption, arguing that even if we assume that a fetus is a full person with a right to life, abortion can still be morally acceptable. Thomson begins her argument with the violinist case, a case in which she contends that your right to control your body 
trumps another person's right to life. This case is generally accepted to be analogous to pregnancy resulting from rape. Thus if Thomson has shown that we have a right to unplug ourselves from the violinist, then she has given us good reason to think that we have a right to perform abortion in at least some extreme cases. In "Abortion and Ownership," John Martin Fischer argues that in the violinist case you do not have the right to unplug yourself from the violinist. He contends that Joel Feinberg's cabin case has demonstrated that a right to life trumps one's right to property. Therefore, if we understand our right to control our body as a form of property right, the violinist's right to life is stronger than our right to control our body, undermining Thomson's defense of abortion.

I contend that Fischer's criticism of Thomson's position fails because our right to control our body is best understood as a right to liberty, not as a property right. I also argue that Fischer and Thomson's interpretations of the cabin case go awry. Both contend that in Feinberg's cabin case the stranger who breaks into a cabin to save his life acts morally. However, they go on to contend that the stranger has a moral obligation to apologize for his breaking and entering, and make restitution. If the stranger's breaking into the cabin was morally justified, she has done nothing wrong for which she should apologize. Furthermore, while offering restitution in this case is acceptable, I argue that it is not morally obligatory because one's ability to pay restitution is a matter of luck and one cannot be morally blameworthy for matters of luck.

This paper is divided into two sections. In the first, I review the role that Thomson's violinist case plays in her overall argument in defense of abortion. In the second, I critique Fischer's series of cabin cases meant to bridge the gap between the Feinberg's cabin case and Thomson's violinist case. I argue that the stranger's right to life trumps the cabin-owner's right to property, but not the cabin-owner's right to liberty.

For the purposes of this paper, I make, but not argue for, three assumptions. First, to have the right to something does not mean that exercising that right is morally praiseworthy. For example, your property right in your car allows you to destroy your car, say, by pushing it off a cliff. But this does not mean that it is morally praiseworthy for you to push your car off a cliff, only that all else being equal others are not allowed to interfere with your pushing your car off a cliff. Second, if you have a moral obligation to do $x$ and fail to do $x$, you are blameworthy for failing to do $x$ to a non-zero degree. For example, if you have a moral obligation to get your child vaccinated, and you fail to do so, you are blameworthy for failing this obligation.

Lastly, I will assume that the control principle is true, where according to the control principle to be morally responsible for $x, x$ must be in your control. Although philosophers disagree about the nature of control this principle requires, most moral philosophers agree that if moral responsibility is possible, some interpretation of the control principle is true. For example, it would not make sense to hold you morally responsible for the extinction of the dinosaurs because it was something over which you had no control Fischer contends that moral responsibility requires what he calls "guidance control": one is morally responsible for an act if 
and only if it arises from an agent's reason-responsive mechanism. (Fischer 1994; Fischer and Ravizza 1998)

Here I will interpret the control principle as being inconsistent with holding people morally responsible for matters of luck, where a matter of luck is something that is outside of one's control. (Nagel 1976) On this interpretation of the principle, we are not actually morally responsible for the consequences of our actions because these are a matter of luck. At best, we are truly morally responsible for our free choices that led to those consequences and derivatively morally responsible for the consequences of these choices, where derivative moral responsibility is responsibility derived from some prior action. (Simkulet 2014: 2015)

\section{Violinist Case}

Because most anti-abortion arguments seek to show that a fetus has a right to life, Thomson begins her defense of abortion by assuming what those opposed to abortion seek to show - that a fetus has a right to life. She continues, "No doubt the mother has a right to decide what shall happen in and to her body; everyone would grant that." (Thomson 1972: 48) The anti-abortion argument contends that the fetus's right to life trumps the woman's rights with regard to her body, and as such the woman does not have a right to perform an abortion and abortion is morally wrong.

As a counter-example to this argument, Thomson constructs the violinist case:

\section{Violinist case 1:}

The Society of Music Lovers kidnaps you and attaches your circulatory system to a famous, innocent, unconscious violinist suffering from a kidney ailment that will kill him unless he remains connected to the your kidneys for 9 months. (Adapted from Thomson 1972: 49-50)

All else being equal, it would be praiseworthy of you to choose to stay attached to the violinist for the next 9 months to save his life, but Thomson contends that, intuitively, it is not obligatory to do so. It is uncontroversially true that the violinist has a right to life. It would be quite odd if his right to life was somehow taken away by the immoral actions of the Society of Music Lovers. But it seems that the violinist's right to life does not give him the right to use your body. It does not trump your rights to your own body. ${ }^{1}$

If Thomson's intuitions regarding the violinist case are correct, the violinist's right to life does not trump your rights to your body. Because the violinist case is relevantly analogous to cases of pregnancy resulting from rape (an innocent life is

\footnotetext{
${ }^{1}$ Although Thomson contends that abortion is not always impermissible, she contends that it might not always be permissible; for example there may be situations in which being a minimally decent Samaritan requires that one go through with the pregnancy. (Thomson 1972: 65) For example, suppose that there was a breakthrough in incubator technology, and fetuses could be safely removed from a mother and safely grow to maturation in these new incubators starting at 2 weeks. A minimally decent Samaritan might be required to carry the fetus for two weeks and then get it safely removed, rather than being allowed to perform an abortion.
} 
put in a situation by the immoral acts of others where it needs to stay attached to you for 9 months or it will die), then it seems that abortion is at least prima facie morally acceptable in rape cases for the same reasons disconnecting yourself from the violinist is acceptable in the violinist case.

Some anti-abortion theorists do not make an exception for rape cases-Thomson calls this "the extreme view"; this view is prima facie inconsistent with the intuition that you can unplug yourself from the violinist. (Thomson 1972: 50) Of course, many anti-abortion theorists are willing to make exceptions for extreme cases, such as cases of pregnancy resulting from rape or cases where the mother's life is in danger. But most cases of pregnancy are not these kinds of cases. Most pregnancies result from consensual sex (with or without contraception). One anti-abortion argument goes as follows: When one freely engages in consensual sex knowing that it may result in pregnancy, one has freely consented to becoming pregnant and it would be unacceptable to kill the fetus after consenting to get pregnant so you must allow the fetus the use of your body for nine months or so. Alward (2012) makes a similar argument, contending that parents (at least fathers) gain their parental obligations through (negligent) acts of sexual intercourse. This argument can be summarized as follows:

The consent argument:

1. The consent principle-When an agent $a$ freely engages in action $x, a$ consents to all possible foreseeable consequences of $x$.

2. Pregnancy is a possible foreseeable consequence of sexual intercourse.

Conclusion: Therefore, when two (sufficiently informed) human agents freely

choose to engage in sexual intercourse, they have consented to pregnancy.

Thomson contends that this is absurd, "for by the same token anyone can avoid a pregnancy due to rape by having a hysterectomy, or anyway by never leaving home without a (reliable!) army." (Thomson 1972: 59) The circumstances that we face are, largely, outside of our control. But whether we have invasive surgery to remove our reproductive organs is, largely, within our control. It is uncontroversially true that any of us might be raped at some point in the future. Therefore, according to this argument, women who realize that rape is possible but who do not have a hysterectomy have consented to becoming pregnant from sexual assault. Similarly, according to Alward's argument, any male who does not have a foolproof vasectomy has acted negligently and has a parental obligation to any children that may result from others sexually assaulting him.

The consent argument is unsound; the consent principle, as described above, has absurd implications. Note that these implications are not restricted to matters of pregnancy according to the consent principle because getting into a car accident is a possible foreseeable consequence of owning a car. Anyone who owns a car has consented to get into a car accident. Because unprovoked sexual activity-what we would normally call rape or nonconsensual sex-is a possible foreseeable consequence of living in a world like ours, then all unprovoked sexual activity is consensual. Because each of us has probably had plenty of opportunity to take our own lives, and chosen not to, then nothing that can be done to us counts as nonconsensual because by choosing not to commit suicide, we have consented to it. 
This is, of course, absurd, and so we have good reason to think the consent principle is false.

Despite the problems with the consent principle, the anti-abortion argument seems to need a pseudo-consent principle as a means of (morally) connecting our free choices with unlikely outcomes, such as pregnancy resulting from consensual sexual intercourse using contraception. What Thomson's violinist case does is provide a litmus test for any pseudo-consent principle — such a principle must be able to tell the difference between unplugging from the violinist or abortion in rape cases - both of which are prima facie morally acceptable - and abortion in cases of consensual sex (with or without contraception), which the anti-abortion argument seeks to condemn. If it cannot, then the anti-abortion argument either fails to show that abortion is wrong in cases of consensual sex, or it has an absurd implicationthat women or men who have been foreseeably sexually assaulted have consented to producing children by not getting a hysterectomy or a foolproof vasectomy.

\section{Cabin Cases}

Fischer contends that he initially shared Thomson's intuition that you could unplug yourself in the violinist case, but that upon reflecting on Feinberg's cabin case he came to revise his initial intuition. (Fischer 2013: 279) Although the cabin and violinist cases seem different, Fischer constructs a series of cases designed to bridge the gap between the two. Feinberg's cabin case can be summarized as follows:

\section{Cabin case 1:}

You own a remote mountain cabin in the high mountain country. As it so happens, a stranger is hiking the area when an unanticipated blizzard strikes the area with such ferocity that her life is imperiled. Fortunately, she stumbles across your unoccupied cabin-locked and boarded up for later in the winter when such blizzards are a more likely occurrence. She smashes a window, enters, and stays in your cabin until the storm abates, eating your food and burning your wooden furniture to keep warm. (Adapted from Feinberg 1978: $102^{2}$ )

According to Feinberg, the stranger's actions are surely justified. Fischer contends that in this case the stranger also obtains an obligation to "explain what has happened to the owner, apologize for the intrusion and damage ... caused, and make amends financially." (Fischer 2013: 277) Thomson agrees with Fischer that the interloper has infringed upon the cabin owner's rights. (Thomson 1980:3) It strikes me that both Fischer and Thomson's accounts of the stranger's activities here are problematic.

First, Fischer contends that the stranger owes you an apology for breaking into your cabin. But an apology involves an admission of wrongdoing and Feinberg, Fischer, and Thomson seem to all agree that the stranger would be morally justified

\footnotetext{
${ }^{2}$ Note: in Feinberg's original case, you do the breaking into another's cabin. Here I've reversed the ownership roles to make the case more analogous to Thomson's violinist case.
} 
in breaking into the cabin in this case-that is to say that the she does nothing wrong, and thus has nothing for which to apologize.

Thomson contends the intruder violates the cabin owner's property rights. But this would be akin to saying that you violate the violinist's right to life when you unplug him from you. However, if our intuitions in the violinist case are correct, then our rights regarding our body trump the violinist's right to life. So we have the right to do so. Although you might express regret over what is going to happen to the violinist, you do not have a moral obligation to apologize to him for exercising your rights because you have done nothing wrong. The violinist's right to life does not allow him to justly use your body however he wants. Similarly, if the stranger's right to life trumps your right to property, your right to property does not prevent the stranger from justly breaking in (it merely limits the circumstances in which breaking in would be morally acceptable; a break in during the middle of summer when her life is not in danger would be morally wrong).

Although one might express regret regarding the circumstances or the outcome, it would be inappropriate for the stranger to apologize for breaking into your cabin. The difference here is the same difference between saying "I am sorry for your loss" to comfort an acquaintance after the death of their mother, and "I am sorry" to apologize for shooting your acquaintance's mother after coming to regret the action you always knew was morally wrong.

Thomson contends that to say the stranger has not infringed upon your property rights in the cabin case would require our concept of ownership to be even more complex than is normally thought to be. However, all parties involved agree that the morally correct thing to do is to break into the cabin. Thus if rights violations are blameworthy (and I do not see how they could not be), for Thomson it seems that the stranger has stumbled into a morally blind alley, where regardless of what she does, she will act in a blameworthy manner. But this is inconsistent with the control principle, as luck regarding the circumstances one faces would make one blameworthy regardless of how one chose to act.

Otsuka (1998) develops and defends the principle of avoidable blame, according to which to be morally responsible for something requires the ability to act in a manner in which one is entirely blameless. According to this principle, either at least one of the stranger's options in the cabin case is acceptable, or they all are. ${ }^{3}$ In that all parties agree the stranger is justified in breaking into the cabin, it strikes me that this is the most likely candidate for a blameless action. To say an action is "just" is merely to say that it is blameless and praiseworthy.

\footnotetext{
${ }^{3}$ Otsuka's principle entails incompatibilism, or the view that free will and moral responsibility require multiple possible futures. (Otsuka 1998) Fischer is a semi-compatibilist and believes that moral responsibility is consistent with there being only one possible future. In "Blame and A voidability: A Reply to Otsuka," John Martin Fischer and Neal A. Tognazzini argue that Otsuka's principle is vulnerable to Frankfurt-style cases-cases in which an agent is supposed to be morally responsible despite lacking multiple possible futures (Fischer and Tognazzini 2010). In "A rejoinder to Fischer and Tognazzini," Otsuka argues his principle is immune the Fischer and Tognazzini's Frankfurt-style case (Otsuka 2010). The debate between compatibilists and incompatibilists is highly contentious, and within this debate there is a wide body of literature built around Frankfurt-style cases that is too large to cover here. See Frankfurt $(1969,2006)$, Widerker (1995), and Kane (1996) for the heart of the debate.
} 
Michael Otsuka's principle seems to capture our commonsense notion that there are no morally blind alleys while at the same time giving us a practical means to calculate moral blame in situations which masquerade themselves as no-win scenarios. According to Otsuka, choosing the least bad outcome is entirely blameless. Feinberg, Fischer, and Thomson all agree that breaking into the cabin is morally acceptable, despite the damage to the cabin owner's property. This is because the damage to the owner's cabin is inconsequential when compared to the life of the stranger. The alternative-which Fischer and Thomson perplexingly seem to advocate-is to hold that the stranger is morally justified in breaking into the cabin - this is the right thing to do-and to hold that the stranger is morally blameworthy for violating the cabin owner's rights. Thus the agent is blameworthy for doing the right thing. But this is absurd.

Fischer contends that the stranger would be required to pay restitution to the cabin owner. Perhaps on this view the stranger is not blameworthy until he fails to fulfill obligations that came in tandem with his morally acceptable action. However, suppose that the stranger cannot pay the restitution. Suppose that the only furniture in the cabin available to burn was priceless antiques that were impossible to replace. In this case, restitution is impossible. But if the stranger incurs a moral obligation to pay restitution as a result of breaking in and restitution is impossible, then she would be blameworthy through no fault of her own. If Fischer is correct, once again we would be faced with the absurd conclusion of the stranger's right action (breaking into the cabin and burning the furniture) resulting in her being morally blameworthy.

All else being equal, it makes sense to want to compensate others for the problems you have caused them, and often times compensation might be morally obligatory. But it cannot be obligatory in all cases because whether compensation is possible is, ultimately, a matter of luck and outside of anyone's control. ${ }^{4}$

Fischer asks us to consider a variant of the cabin case in which you, the cabin owner, are home during the storm. (Fischer 2013:277) He contends that as the cabin owner you would have a moral obligation to allow the stranger into your cabin. No window is broken (because you let her in), and no furniture is burned (because you have brought other wood to burn). Note: It strikes me that if you decide not to let the stranger in, the stranger is justified in breaking in none the less.

Fischer then asks us to consider the following variant:

Cabin case 2: Extreme variant.

You have secured a cabin in a remote part of the Himalaya mountains so that you can be alone. You have brought enough supplies for yourself and extras in case an emergency arises. As it so happens, a very evil man has kidnapped an innocent stranger and brought her to the Himalaya mountains to die. This stranger comes across your cabin.

It occurs to you that either you let the stranger in, saving her life, or your leave her out in the cold to die. The stranger is too weak to break in on her own. Because of the remote location, if you allow the stranger in, you will not be able to get rid of her for 9 months. (Adapted from Fischer 1991:6) 
Here Fischer claims you still have a moral obligation to allow the stranger into your home. Although you own the cabin and housing the stranger will be an inconvenience, he contends that you are still morally obligated to do so. The stranger's right to life trumps your right to property.

Fischer asks "Why is it permissible in the violinist example but not the Cabin Case so to act that the innocent person dies?" (Fischer 2013: 279) The answer, it seems, is that the relevant right in Thomson's violinist case is not your property right to your body, but rather your right to liberty, freedom, or autonomy. ${ }^{5}$ Although the cabin case demonstrates that a right to life trumps a right to property (at least when the property is not necessary to stay alive), it does not show that the right to life trumps the right to liberty, conceived in the violinist case as the right to decide what happens to (and in) your body. Although it may make sense to say that we have a property right to our body, our ownership of our bodies is fundamentally different than our ownership of, say, a car, or even the ownership one was said to have over enslaved human beings.

Fischer, however, seeks to close the supposed gap between the violinist case and the cabin case with the following cases:

\section{Violinist case 2: Surgery variant}

You are in a major accident and, after surgery, you are confined to bed for 9 months with your kidneys attached to a machine. A representative of the Society of Music Lovers sneaks in one night and plugs the unconscious, innocent violinist into your kidney via the machine. (Adapted from Fischer 2013: 280)

\section{Cabin case 3: Tiny Person Variant}

You have secured a cabin in a remote part of the Himalaya Mountains so that you can be alone. You have brought enough supplies for yourself and extras in case an emergency arises. As it so happens, a very evil man has kidnapped a tiny stranger and brought her to the Himalaya Mountains to die. The stranger comes across your cabin. After letting the tiny stranger in, because of your advanced medical training you realize that the tiny stranger will die unless you carry her on your back for 9 months. (Adapted from Fischer 2013: 280-281)

According to Fischer, you are morally obligated to stay attached to the violinist in violinist case 2 , and morally obligated to carry around the tiny stranger in cabin case 3. Although I am inclined to agree that, all else being equal, you probably have a strong moral obligation to stay attached in violinist case 2 and you might as well carry around the tiny stranger in cabin case 3, I am not quite so sure that either party has a right to this. Consider the following cases:

\footnotetext{
${ }^{5}$ It is, I think, easy to equivocate between Thomson's conception of your right to control your body and property rights in virtue of her expanding baby case. In this case you find yourself trapped in a house with a rapidly growing child. Thomson argues that in this case a third party has a non-arbitrary rationale for saving your life over the child's life because the child is in your home. It is innocent, by stipulation, but your property right in your home gives the third party a reason to seek to intervene on your behalf. (Thomson 1972: 52) By analogy, abortion to save the mother's life is justified because the mother's ownership of her body gives you a reason to intervene on her behalf. Although it is true the mother owns her body, this ownership is more substantive than normal ownership, and one's rights to one's body are different than normal property rights.
} 


\section{Violinist case 3: Rapist variant.}

You are in a major accident and, after surgery, you are confined to a bed for 9 months with your kidneys attached to a machine. A representative of the Society for Giving Rapists a Second Chance sneaks in one night and plugs an unconscious, restrained man into your kidney via the machine. You awake and immediately recognize the man attached to your kidney as the man who raped your daughter earlier this year.

\section{Cabin case 4: Back Problems variant}

You have secured a cabin in a remote part of the Himalaya Mountains so that you can be alone. You have brought enough supplies for yourself and extras in case an emergency arises. As it so happens, a very evil man has kidnapped a tiny stranger and brought her to the Himalaya Mountains to die. The stranger comes across your cabin. After letting the tiny stranger in, because of your advanced medical training you realize that the tiny stranger will die unless you carry her on your back for 9 months. However, you have a history of back problems and are afraid that if you carry the tiny person on your back for any extended period of time, you might fall due to back injury and not be able to get up, leading to your death and the death of the tiny person on your back.

It is uncontroversially true, I think, that the risk posed to you by pseudo-pregnancy in cabin case 4 is sufficient for you to refuse to carry the tiny person on your back. The right to life of the tiny person does not trump your right to life. Your rights and obligations with regards to your own life allow, and perhaps even obligate, you to deny the tiny person access to your back even though doing so will lead to her death.

Less uncontroversial, though, are my intuitions about violinist case 3. My intuition here is that you not only have the right to deny the rapist (and the pseudorapist - the representative of the Society for Giving Rapists a Second Chance) access to your kidneys, but that it is morally acceptable for you to do so. Thomson contends that there are situations where a minimally decent Samaritan might be morally obligated to give of herself. But I do not think this is one of those cases. Although you would be confined to bed for 9 months either way, whether or not your kidneys are used to save the life of the man who raped your daughter seems like something that should be entirely within your control. No doubt some people would, reluctantly, allow the rapist to stay attached to their kidneys. But this is a step beyond even the rape victim who allows their innocent child conceived from rape access to her body. The rapist is, by stipulation, morally blameworthy and our

moral obligations towards immoral agents are uncontroversially different than those towards innocent moral agents.

Consider one final variant of the violinist case:

Violinist case 4: Racist variant.

You are in a major accident and, after surgery, you are confined to a bed for 9 months with your kidneys attached to a machine. A representative of the Society of Music Lovers sneaks in one night and plugs an unconscious, innocent man into your kidney via the machine. You awake and immediately recognize the man attached to your kidney as a famous violinist that happens 
to be of a different race. And then it occurs to you that you believe your race is superior to the race of this man, and because of this you request to be unattached immediately.

Here I would side with Fischer in contending that you have a strong moral obligation to stay attached to the violinist. Despite this, I have the intuition that you have a right to disconnect yourself from the violinist, even though being attached to the violinist does not cost you anything (except, perhaps, your peace of mind). The violinist clearly has a right to life, but you have a right to liberty, and your right to liberty (unfortunately in this case) includes the right to refuse others access to your body without permission-even if access to your body is necessary to save their life and if their life is something that, objectively, you have a moral obligation to save.

Earlier, I made the assumption that just because you have a right to something does not mean that exercising that right is morally acceptable. All else being equal, you have a right to push your car off a cliff. But you should not do so because cars are expensive and pushing it off a cliff would be an incredible waste. If, however, your friend is having an allergic reaction to a bee sting and the only way to save his life is for him to drive your car to the hospital, you do not have a right to restrict him access to your car, nor do you have a right to push it off the cliff until after he is safe. The right to life trumps the right to property.

Thomson's original violinist case seems to demonstrate that the right to life does not trump the right to liberty. Consider a final case wherein the only way to save your friend is to give him access to your kidneys. While I have the intuition that the morally right thing to do is to save him, I also have the intuition that you have the right to refuse him access to your kidneys: to refuse would be morally wrong-and blameworthy. He is, after all, your friend. However, because you have a right to liberty it would be morally wrong-and blameworthy-for others to force you to give your friend access to your kidneys against your will because in doing so they would take away your liberty and make you a slave to his wishes.

Although the violinist in Thomson's case is both innocent and not responsible for his being connected to you, this does not mean that his right to life gives him a right to usurp your liberty and use you as a means to keep himself alive. In some situations, such as Violinist 2 where a prior event has already radically curtailed your liberty, you may have a strong moral obligation to stay attached to the violinist. However, Violinist 3 shows that, intuitively, you ought to have some say over how your body is used even in extreme cases where your liberty is already partially curtailed.

\section{References}

Alward, Peter. 2012. Abortion rights and paternal obligations. Public Affairs Quarterly 26(1): 273-291. Devine, Philop. 1978. The ethics of homicide. Ithaca: Cornell.

Engelhardt, H. Tristram. 1974. The ontology of abortion. Ethics 84(3): 217-234.

Feinberg, Joel. 1978. Voluntary euthanasia and the inalienable right to life. Philosophy \& Public Affairs 7: 93-123. 
Feinberg, Joel. 1986. Abortion. In Matters of life and death: new introductory essays in moral philosophy, ed. Tom Regan, 256-293. New York: Random House.

Fischer, John Martin. 1991. Abortion and self-determination. Journal of Social Philosophy 22: 5-13.

Fischer, John Martin. 1994. The metaphysics of free will. Oxford: Blackwell.

Fischer, John Martin. 2013. Abortion and ownership. Journal of Ethics: An International Philosophical Review 17(4): 275-304.

Fischer, John Martin, and Mark Ravizza. 1998. Responsibility and control. Cambridge: Cambridge University Press.

Fischer, John Martin, and Neal A. Tognazzini. 2010. Blame and avoidability: a reply to Otsuka. The Journal of Ethics 14(1): 43-51.

Frankfurt, Harry G. 1969. Alternate Possibilities and Moral Responsibility. The Journal of Philosophy 66(23): 829-839.

Frankfurt, Harry G. 2006. Some thoughts concerning PAP. In Moral responsibility and alternative possibilities essays on the importance of alternative possibilities, ed. Widerker, David and McKenna, Michael, 339-345. Ashgate.

Kane, Robert. 1996. The significance of free will. New York: Oxford University Press.

Marquis, Don. 1989. Why abortion is immoral. Journal of Philosophy 86(4): 183-202.

Nagel, Thomas. 1976. Moral luck. Proceedings of the Aristotelian Society 50: 137-151.

Noonan, John T., Jr. 1970. An almost absolute value in history. In The morality of abortion: legal and historical perspectives, ed. John T. Noonan, Jr., 51-59. Cambridge: Harvard.

Otsuka, Michael. 1998. Incompatibilism and the avoidability of blame. Ethics 108(4): 685-701.

Otsuka, Michael. 2010. A rejoinder to Fischer and Tognazzini. The Journal of Ethics 14(1): 37-42.

Simkulet, William. 2014. In control. Philosophical Inquires 2(1): 59-75.

Simkulet, William. 2015. The compensation principle. Filosofiska Notiseri 2(1): 47-60.

Sumner, L.W. 1981. Abortion and moral theory. Princeton: University Press.

Tooley, Michael. 1972. Abortion and infanticide. Philosophy \& Public Affairs 2(1): 37-65.

Thomson, Judith Jarvis. 1972. A defense of abortion. Philosophy \& Public Affairs 1(1): 47-66.

Thomson, Judith Jarvis. 1980. Rights and compensation. Noûs 14: 3-15.

Warren, Mary Anne. 1973. On the moral and legal status of abortion. The Monist 57(4): 43-61.

Widerker, David. 1995. Libertarianism and Frankfurt's attack on the principle of alternative possibilities. Philosophical Review 104: 247-261.

Wirt, William. 1836. Sketches of the life and character of Patrick Henry. Philadelphia: Desilver, Thomas $\&$ co. 